\title{
枝管付きループ管型熱音響冷凍機における冷却性能の数值シミュレーション Numerical Simulation of Thermoacousic Cooling in Loop-Tube-Type Cooler with Branch Resonator
}

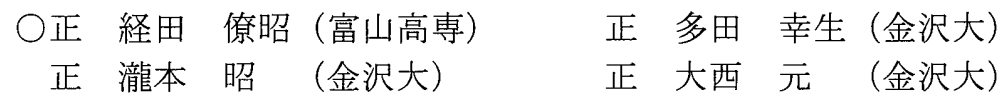

Tomoaki Kyoden, Yukio Tada, Akira Takimoto and Hajime Onishi

Toyama National College of Technology , 1-2 Ebie-Neriya, Imizu-shi, Toyama 920-0941

Kanazawa University, Kakuma, Kanazawa 920-1192

\begin{abstract}
Thermoacoustic cooler is one of promising technique for utilization of unused thermal energy. The object of this paper is to study acoustic field and temperature field in looped-tube-type thermoacoustic cooler. Using finite-difference time-domain (FDTD) method and energy equations, pressure, particle velocity and temperature were numerically simulated for various stack structure. By propagating sound in the stack, the temperature gradient was generated. It was also found that the effect of thermoacoustic cooling depends on mesh size in the stack. Summarizing these results, the mechanism of thermoacoustic cooling was discussed in relation to thermal response of stack and phase difference.
\end{abstract}

Key Words: Thermoacoustic Cooler, FDTD Method, Energy Equation, Stack Structure

\section{1. 緒言}

スタック（微細な流路を多数有する蓄熱体）内を伝播す る音波による熱の輸送現象を利用した熱音響冷却技術は， 冷媒が不要で可動部が無い簡単な構造で実現される廃熱駆 動型の泠却システムとして注目され，活発に研究がなされ ている(1). しかし, 現状では冷却性能は低く, 流路やスタ ックなどの装置形状を含めた高性能化が必要であり，その ためには音波による熱輸送機構のさらなる詳細を追究する 必要がある。

本研究は以上の観点から，代表的な装置形状である枝管 付きループ管型熱音響冷凍機を対象に，音波による熱輸送 現象と冷却性能をスタック構造と関連づけて理論的に追究 するものである。これまでに著者らは，FDTD 法を用いた 音場解析モデルを構築すると共に ${ }^{(2)}$, スタック部の伝熱解 析により進行波音波による熱輸送効果を明らかにしてきた (3). 本報は定在波成分と進行波成分が複合した枝管付きル 一プ管を対象に，熱音響場の数值計算を行い，スタック内 の温度場の詳細を明らかにするとともに，音波の熱輸送効 果をスタック内の細孔流路径と関連づけて理論的に追究し たものである。

\section{2. 数值シミュレーション}

\section{1 解析モデル}

解析モデルを Fig.1 に示す. 枝管(長さ $180 \mathrm{~mm}$ ) とループ 管(周長 $860 \mathrm{~mm}$ )からなる大気圧空気が封入された熱音響冷 凍機内部の二次元空間を対象とする. $X$ 座標の原点は枝管 下端とし， $X=710 \mathrm{~mm}$ から金属繊維積層体のスタック $(50 \mathrm{~mm})$ が設置されている. 解析は, まずループ管全体の音 場計算を行い(Fig.1(a)), その計算結果を別領域に移行させ (Fig.1(b)), スタック部の温度場の解析を行った。

\section{2 基礎式}

音場の基礎式を(1)〜 (3)に示す. 式中の $p$ は音圧, $v_{x}, v_{z}$ は粒子速度である. $\kappa$ は体積弾性係数で $\kappa=\rho \mathrm{c}^{2}=\rho \gamma \mathrm{R} T(\gamma$ : 比熱 比， R:気体定数)とした。 $\eta$ は空気部に音波の減衰係数を, スタック部に金属繊維多孔体の流れ抵抗 ${ }^{(4)}$ をえた. 気相 のエネルギー式は移流項(Aterm), 圧力項(Pterm), 熱伝導項 (HCterm)からなる式(4)とした。

境界条件として，枝管・ループ管壁面での音波のエネル ギー損失を考慮するため吸収層を設け，その外側を剛体壁
とした。また，温度場の計算では，熱交換器の設置を想定 し，スタック上端は $290[\mathrm{~K}]$ で一定とした. スタックは Table 1 に示されるように，空隙率一定で目開きの大きさが異な る 5 種類の SUS 製メッシュを積層した構造とした. 振動面 から $1.12 \mathrm{kPa}, 110 \mathrm{~Hz}$ の音波を入射させ，圧力，粒子速度， 気相とスタックの温度の計算を行った。
(音場)[連続の式]

$\frac{\partial p}{\partial t}=-\kappa\left(\frac{\partial v_{x}}{\partial x}+\frac{\partial v_{z}}{\partial z}\right)$

(温度場) [気相 (空気) ]
[運動方程式]

$$
-\rho \frac{\partial v_{x}}{\partial t}=\frac{\partial p}{\partial x}+\eta v_{x}
$$$$
-\rho \frac{\partial v_{z}}{\partial t}=\frac{\partial p}{\partial z}+\eta v_{z}
$$

$$
\begin{array}{r}
\rho c_{p} \frac{\partial T}{\partial t}=-\rho c_{p}\left[v_{x} \frac{\partial T}{\partial x}+v_{z} \frac{\partial T}{\partial z}\right]+\left[\frac{\partial p}{\partial t}+v_{x} \frac{\partial p}{\partial x}+v_{z} \frac{\partial p}{\partial z}\right]+\lambda\left(\frac{\partial^{2} T}{\partial x^{2}}+\frac{\partial^{2} T}{\partial z^{2}}\right) \\
\left(A_{\text {term }}\right) \quad\left(P_{\text {term }}\right) \\
\left(H C_{\text {term }}\right)
\end{array}
$$

[スタック(ステンレス板)]

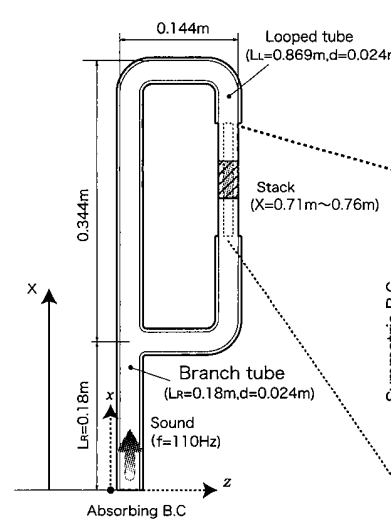

(a) Acoustic field

$$
\rho_{s} c_{s} \frac{\partial T_{s}}{\partial t}=\lambda_{s}\left(\frac{\partial^{2} T_{s}}{\partial x^{2}}+\frac{\partial^{2} T_{s}}{\partial z^{2}}\right)
$$

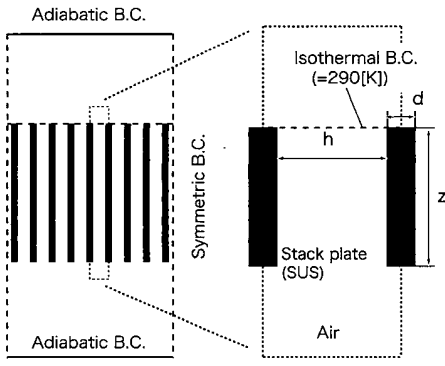

Fig.1 Analytical model

Table 1 Geometric parameter of Stack

\begin{tabular}{|c|c|c|c|c|c|c|}
\hline \multicolumn{3}{|c|}{ Mesh parameter } & \multicolumn{3}{|c|}{ Stack parameter } \\
\hline $\begin{array}{c}\text { Mesh } \\
\text { size } \\
\text { No. }\end{array}$ & $\begin{array}{c}\text { Wire } \\
\text { diameter } \\
{[\mathrm{mm}]}\end{array}$ & $\begin{array}{c}\text { Aperture } \\
\text { size } \\
{[\mathrm{mm}]}\end{array}$ & Porosity & $\begin{array}{c}\text { Number } \\
\text { of mesh }\end{array}$ & $\begin{array}{c}\text { Hydrodynamic } \\
\text { radius [mm] }\end{array}$ & $\begin{array}{c}\text { Thermo- } \\
\text { acoustic } \\
\text { parameter } \\
\omega \tau\end{array}$ \\
\hline \hline$\# 16$ & 0.45 & 1.14 & 0.758 & 68 & 0.341 & 1.83 \\
\hline$\# 22$ & 0.33 & 0.825 & 0.742 & 92 & 0.245 & 0.943 \\
\hline$\# 30$ & 0.25 & 0.597 & 0.765 & 120 & 0.187 & 0.552 \\
\hline$\# 50$ & 0.16 & 0.348 & 0.748 & 188 & 0.109 & 0.189 \\
\hline$\# 60$ & 0.12 & 0.303 & 0.771 & 250 & 0.094 & 0.14 \\
\hline
\end{tabular}




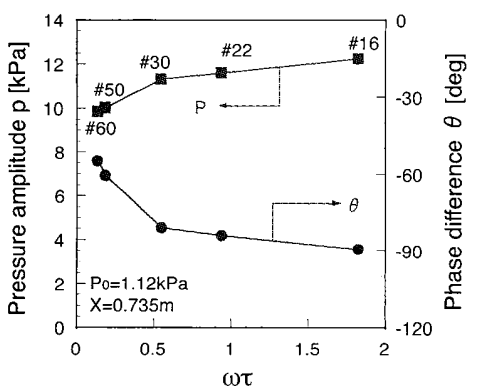

Fig.2 Effect of of $\omega \tau$ on pressure amplitude and phase difference in stack

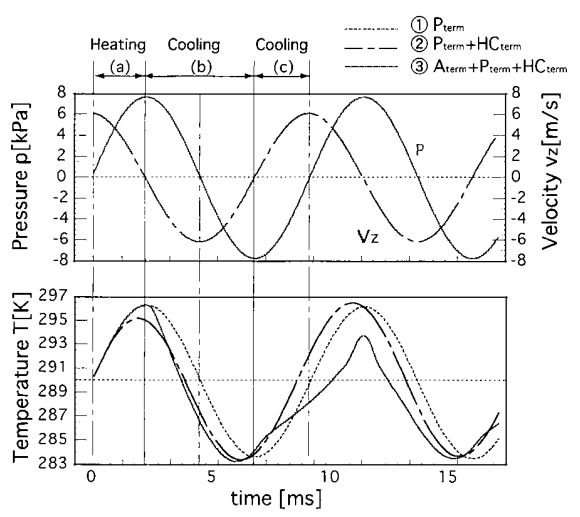

Fig. 3 Sound characterisitcs and temperature wave-form in stack (\#16mesh)

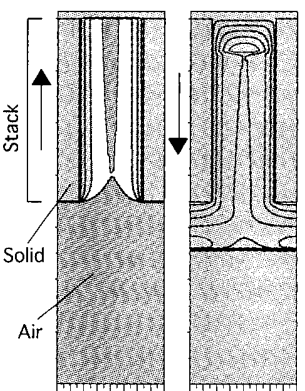

$\begin{array}{lll}\text { (1) } 0.1 \text { cycle } & \text { (2) } 0.5 \text { cycle (3) } 0.75 \text { cycle }\end{array}$ Fig.5 Temperature distribution in stack (\#16mesh)

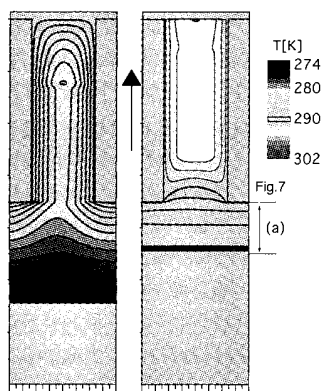

(4) 1 cycle

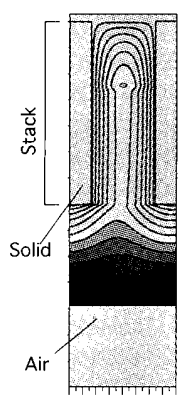

(a)\#16mesh
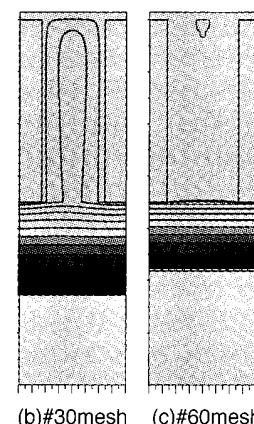

Fig.6 Temperature distribution in stack $(0.75 \mathrm{cycle})$

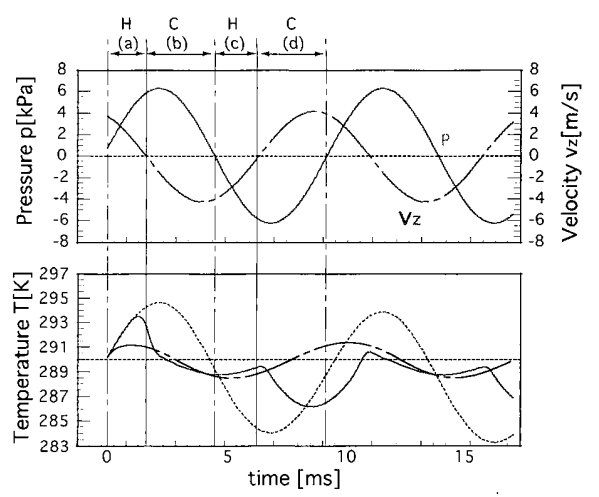

Fig.4 Sound characterisitcs and temperature wave-form in stack (\#60mesh)

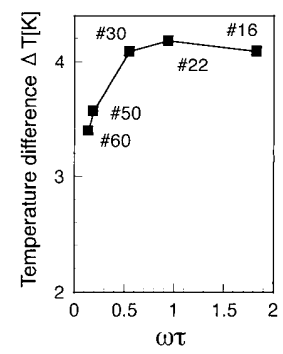

(a) Calculation

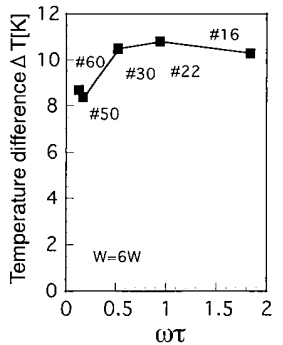

(b) Experiment
Fig.7 Effect of of $\omega \tau$ on thermoacoustic cooling

\section{3. 枝管付きループ管型熱音響冷凍機における熱音響特性 3.1 音場特性}

スタック内の固体壁面と作動流体の閒の熱交換の応答性 は音波の角振動数 $\omega$ と熱的緩和時間 $\tau$ の積で定義される無 次元数 $\omega \tau=\omega r_{0}{ }^{2} /(2 a)\left(\omega\right.$ :音波 $の$ 角振動数, $r_{0}$ : 水力半径, $a$ : 温度伝導率）で表される。ループ管内のスタック中央にお ける圧力振幅, および圧力と粒子速度の位相差を Fig.2 に 示す. $\omega \tau$ の小さなスタック，すなわち水力半径の小さなス タックほど粘性による流れ抵抗が大きくなり，圧力振幅が 減少し，位相差が増加寸ることが分かる。

\section{2 音波による熱輸送機構}

\#16 メッシュを用いたスタックについて，圧力振幅と粒 子速度，およびスタック内下部の温度の時間変化を Fig.3 に示す。ここで, 温度については気体のエネルギー式を(1) [圧力項], (2) [圧項+熱伝導項], (3) [移流項+圧力項+熱伝 導項]に分解して示す. (1)の温度が圧力と同位相になるのに 対して，(2)の温度は位相が進んでいる。これは，気体一スタ ック壁面間の熱輸送によるもので，気体の温度がスタック 壁面よりも高くなる压縮過程ではスタック壁面への放熱に より (1)よりも早く温度低下し, 膨張過程ではスタック壁面 からの熱流入により (1)よりも早く温度上昇する. 次に(3)の 温度に着目すると, 音波の変位方向と温度勾配で決まる移 流項は，Fig.3 中の(a)で加熱，(b)(c)で冷却となる. その結 果, 最終的な気体の温度は(3)の波形となり, 周期の繰り返 しにより冷却が進行する。

次に， $\omega \tau$ の小さな\#60メッシュを用いたスタックの結果 を Fig.4に示す. (1)(2)の温度波形の比較から, Fig.3 に示し た\#16メッシュ型スタックよりも気体ースタック壁面間の 熱交換量が多く, 気相はよりスタック壁面温度 (ほぼ 290K) に近づくように変化していることが分かる。これは気体一 スタック壁面間の熱交換の応答性の向上によるものである. また，圧力振幅と粒子速度の位相差が大きくなるため，移 流項の影響は図中の (a)(c)で加熱, (b)(d)で伶却となる.

\section{3 スタック内の温度分布}

スタック内の温度分布を Fig.5 に示す. 圧縮過程で上方
に変位する 0.1 周期目では気体の温度が上昇する。このと き, スタック壁面上に温度境界層が形成され, 気体からス タック壁面へ熱が輸送される。下向き変位で膨張過程とな る $0.5 \sim 0.75$ 周期目では, 気体の温度が低下する共に壁面 付近に温度境界層が発達し, 壁面から気体への放熱が進行 する。同時にスタック下方から熱が波み上げられ，スタッ ク下方の気体の温度が低下する. Fig.6にメッシュサイズの 影響を示す。流路サイズが小さくなるにつれて変位振幅が 小さくなり，スタック下方の冷却領域が狭くなる.

\section{4.スタック構造と冷却性能}

熱音響冷凍機ではスタック下端に熱交換器を設置して冷 熱を取り出す。そこで，スタック下方（Fig.5に表示）の空 間領域における 1 周期当たりの気体の空間平均温度を求め, スタック上端温度との差 $\Delta \mathrm{T}$ を冷却性能の指標とした。 Fig.7(a)に 10 周期目の泠却温度差 $\Delta \mathrm{T}$ の計算值を示す. $\omega \tau=1$ 付近で冷却温度差 $\Delta \mathrm{T}$ が最大になる傾向が見られる。 Fig.7(b)に本解析モデルと同寸法の実験装置を用い, スタッ ク両端に熱交換器を設置し, 定常状態で両端に発生する温 度差 $\Delta \mathrm{T}$ を測定した結果 ${ }^{(2)}$ を示す.Fig.7(a)の計算結果は定常 状態に達していないため直接の比較はできないが，定性的 にはFig.7(b)の実験結果に近い傾向であることが分かる.

\section{5. 結言}

枝管付きループ管型熱音響冷凍機を対象に FDTD 法とエ ネルギー式を用いた数值計算を行い, スタック内を音波が 伝播することでスタック両端に温度差が形成される機構を 熱伝導と音波による移流の観点から明らかにした。また， 冷却性能を最大とする熱的応答性 $\omega \tau$ が解析的に示された.

\section{参考文献}

(1)M.M.Basem,Y.Ueda,et al.,Int.J.Refrigeration 34-4(2011),1125

(2)経田,多田,他 3 名,第 48 回伝熱シンポ講論, I (2011), pp.131-132.

(3)経田,多田,他 2 名,第 49 回伝熱シンポ講論, III (2012), pp.589-590

(4)立道, 他 3 名, 機論(B),49-443(1980),1190. 